\title{
ANALISIS DAYA SAING USAHA TERNAK SAPI POTONG RAKYAT DI KABUPATEN MEMPAWAH
}

\author{
ABDUL HAFIDZ HITANI ${ }^{1)}$, NURLIZA $^{2)}$, EVA DOLOROSA $^{2)}$ \\ 1) Alumni Magister Manajemen Agribisnis Fakultas Pertanian Universitas \\ Tanjungpura Pontianak. \\ 2) Staf Pengajar Fakultas Pertanian Universitas Tanjungpura Pontianak
}

\begin{abstract}
This research aims to analyze the development of profitability, productivity, and output growth as well as to analyze the development of the competitiveness of the beef cattle bussiness in Mempawah Regency. This research took placed in 9 Sub-distric in Mempawah. The method used was the descriptive method using the panel data from 2008-2013. The data were processed using the method of ICI (Industrial Competitive Index) by finding out the indicator which included the index of profitability, productivity and output growth. The results of the analysis showed that the growth rate of the profitability index was $15.07 \%$, the productivity index $12.67 \%$ and output growth index $-4.74 \%$. Based on the result of the analysis, the growth rate of the industry competitive index (ICI) for 9 Subdistric in Mempawah Regency overall had a positive value. This indicated that the 9 Sub-distric in Mempawah Regency had the capability of competitiveness. The growth rate of the industrial competitive index for Mempawah Regency was $9.12 \%$.
\end{abstract}

Keywords: people's beef cattle, competitiveness, Mempawah, index.

\section{PENDAHULUAN}

Sektor pertanian telah terbukti memiliki peranan penting bagi pembangunan perekonomian suatu bangsa. Volume ekspor produk pertanian hingga tahun 2008 terbagi dalam empat subsektor, yaitu subsektor tanaman pangan, holtikultura, perkebunan, dan peternakan. Subsektor peternakan secara konsisten sejak tahun 2006 hingga tahun 2008 menyandang status "net importer" yang merupakan kondisi ketika nilai impor suatu negara lebih besar dari nilai ekspor pada komoditas atau produk yang sama. Dilihat dari perkembangannya, Indonesia mengimpor susu (70 persen ), daging sapi (30 ribu ton), dan sapi hidup (450 ribu ekor) per tahunnya. Dari angka-angka tersebut dapat dikatakan bahwa ternak sapi potong merupakan salah satu subsektor peternakan yang mempengaruhi perekonomian nasional.

Salah satu upaya yang diambil pemerintah untuk mengatasi permasalahan ini adalah dengan melalui program swasembada daging. Pemerintah Indonesia mengeluarkan kebijakan swasembada daging pertama pada tahun 2000 dengan pencapaian pada tahun 2004. Program ini tidak berhasil terlaksana pada tahun yang ditentukan, karena masih tidak terpenuhinya kebutuhan daging nasional dengan sumber daya rakyat, sehingga jumlah impor masih tergolong tinggi. Program ini kemudian kembali direvisi untuk pencapaian tahun 2014.

Kabupaten Mempawah merupakan salah satu derah sentra peternakan sapi potong di Provinsi Kalimantan Barat. Usaha ternak sapi potong di Kabupaten Mempawah merupakan sumber daya yang memiliki peluang untuk 
dikembangkan. Selain karena kemampuan untuk menghasilkan input produksi rakyat, juga tersedia tenaga kerja, pakan, lahan, dan konsumsi yang terus meningkat. Potensi pakan ternak di Kabupaten Mempawah dapat dilihat dari luas lahan sawah yang merupakan penghasil tanaman padi sebagai penghasil dedak bekatul dan jerami padi sebagai pakan ternak. selaian itu potensi pakan ternak juga dapat dilihat dari luasan lahan bukan sawah karena pada lahan inilah berbagai macam rumput rumputan sebagai pakan ternak dihasilkan.

Tabel 1. Luasan Lahan Sawah, Lahan Bukan Sawah dan Lahan Bukan Pertanian Di Kabupaten Mempawah tahun 2013 (Ha)

\begin{tabular}{rlc}
\hline No & Jenis Lahan & Luas (Ha) \\
\hline I. & Lahan Sawah & $\mathbf{1 9 . 5 9 3}$ \\
1. & Pengairan Irigasi & 6.701 \\
2. & Tadah Hujan & 8.125 \\
3. & Pengairan Pasang Surut & 4.579 \\
4. & Rawa Lebak & 188 \\
II. & Lahan Bukan Sawah & $\mathbf{9 3 . 9 1 5}$ \\
1. & Tegal/Kebun & 6.498 \\
2. & Ladang/ Huma & 2.496 \\
3. & Perkebunan & 27.872 \\
4. & Hutan Rakyat & 4.274 \\
5. & Pengembalaan & 616 \\
6. & Sementara Tidak Diusahakan & 1.137 \\
7. & Lainnya & 51.022 \\
III. & Lahan Bukan Pertanian & $\mathbf{1 4 . 1 8 2}$ \\
\hline & Jumlah & $\mathbf{1 2 7 . 6 9 0}$ \\
\hline
\end{tabular}

Sumber : satistik penggunaan tanah Kab. Pontianak 2014

Dalam rangka mewujudkan swasembada daging yang telah diprogramkan pemerintah, terdapat beberapa masalah yang harus dihadapi oleh peternakan rakyat seperti halnya di Kabupaten Mempawah. Permasalahan peternak sapi potong rakyat di Kabupaten Mempawah dalam memanfaatkan sumberdaya diantaranya adalah; Pertama, skala usaha dan tujuan usaha peternakan. Usaha peternakan sapi potong di Kabupaten Mempawah masih merupakan usaha rakyat yang tujuan pemeliharaan ternak oleh sebagian besar peternak tesebut tidak diarahkan untuk tujuan pasar. Kedua adalah kontribusi dari wilayah yang populasinya besar masih minim. Kecamatan mempawah timur yang populasinya terbesar, produksi dagingnya cenderung lebih kecil yakni sejumlah 13,40\% ketimbang wilayah sungai pinyuh dan mempawah hilir yang populasinya lebih kecil. Hal ini menyangkut kepada output/produksi daging yang dikeluarkan. Hal ini disebabkan karena ternak dipelihara masih secara tradisional di pedesaan, teknologi budidaya rendah, serta budidaya sapi potong dengan tujuan untuk menghasilkan daging dan berorientasi pasar masih rendah. Masalah Ketiga berada pada tingkat produktivitas ternak sapi potong rakyat. Usaha ternak sapi potong di Kabupaten Mempawah yang banyak dikembangkan dalam skala kecil oleh peternak rakyat akan mempengaruhi produktivitasnya. 
Tabel 2. Populasi Sapi Potong Dan Produksi Daging Di Kabupaten Mempawah Tahun 2013

\begin{tabular}{llcccc}
\hline No & Kecamatan & $\begin{array}{c}\text { Populasi } \\
\text { (ekor) }\end{array}$ & $\begin{array}{c}\text { Persen } \\
\text { tase }(\%)\end{array}$ & $\begin{array}{c}\text { Produksi } \\
\text { Daging } \\
\text { (ton) }\end{array}$ & $\begin{array}{c}\text { Persen } \\
\text { tase }(\%)\end{array}$ \\
\hline 1 & Siantan & 948 & 8,56 & 29,70 & 8,96 \\
2 & Segedong & 705 & 6,37 & 19,85 & 5,99 \\
3 & Sungai Pinyuh & 2.310 & 20,86 & 155,10 & 46,80 \\
4 & Anjungan & 218 & 1,97 & 4,80 & 1,45 \\
5 & Mempawah Hilir & 1.956 & 17,66 & 62,10 & 18,74 \\
6 & Mempawah Timur & 2.860 & 25,82 & 44,40 & 13,40 \\
7 & Sungai Kunyit & 1.281 & 11,57 & 13,95 & 4,21 \\
8 & Toho & 498 & 4,50 & 1,50 & 0,45 \\
9 & Sadaniang & 300 & 2,71 & - & - \\
\hline & Jumlah & 11.076 & 100 & 331,40 & 100 \\
\hline
\end{tabular}

Sumber : Kab. Mempawah dalam angka 2014

Kabupaten Mempawah dalam memenuhi konsumsi masyarakat juga memasukkan sapi bakalan untuk digemukkan di Kabupaten Mempawah. Hal ini tentunya akan menjadi salah satu ancaman tersendiri bagi para peternak sapi rakyat yang rata-rata dikembangkan oleh peternak kecil dan rumah tangga. Banyaknya sapi bakalan yang masuk dari daerah lain, akan melemahkan usaha peternakan rakyat secara perlahan.

Kompetisi antara sapi potong rakyat dengan produk dari daerah lain berupa sapi maupun daging akan terus terjadi. Daya saing peternakan mencerminkan upaya negara dan bangsa untuk tetap memanfaatkan secara maksimal kompetensi sumber daya peternakan untuk meningkatkan kesejahteraan masyarakat. Pemanfaatan sumber daya peternakan sapi potong rakyat secara optimum di tiap kecamatan akan meningkatkan daya saing usaha peternakan sapi potong di Kabupaten Mempawah.

Penyebaran sapi potong rakyat tiap kecamatan yang tidak merata menyebabkan daya saing dari usaha ternak sapi potong rakyat dari masing-masing kecamatan akan berbeda. Dengan mengetahui secara empirik perkembangan daya saing dari usaha ternak sapi potong rakyat pada masing-masing Kecamatan, akan dapat ditentukan kondisi daya saing terbaik yang dapat ditingkatkan untuk meningkatkan daya saing usaha ternak sapi potong rakyat secara agregat.

\section{Landasan Teori}

Konsep daya saing telah digunakan secara luas dalam literatur ekonomi dan bisnis sejak lama, namun demikian terdapat sedikit kesepakatan mengenai definisi daya saing secara tepat sehingga tidak didefinisikan secara baik (ambigu) (Porter, 1990; Krugman, 1994; Siggel, 2007). Adanya keberagaman konsep dan ukuran daya saing disebabkan bervariasinya kebutuhan analisis kebijakan, pandangan dan tujuan penelitian (Bojnec \& Ferto, 2009). Atribut dari isi pokok daya saing juga berbeda pada waktu dan konteks yang digunakan (Ambastha \& Momaya, 2004). Daya saing dapat pula dipandang berdasarkan wilayah (geografis), produk (bentuk) dan waktu (Cook \& Brehdahl, 1991). Berkenaan dengan aspek wilayah, daya saing dapat dilakukan guna membandingkan perusahaan atau perdagangan dalam wilayah di negara tertentu atau antar negara (Bojnec \& Ferto 2009).

Daya saing dapat dianalisis pada tiga tingkatan berbeda seperti tingkat nasional (makroekonomi), tingkat industri (mesoekonomi) maupun tingkat perusahaan (mikroekonomi) (Ambastha \& Momaya 2004; Bojnec \& Ferto 2009). 
Pandangan Krugman (1994) bahkan tidak menyarankan menggunakan konsep daya saing nasional (national economies competitiveness) karena tidak bermakna, sulit dipahami serta obsesi terhadap daya saing adalah salah dan membahayakan.

Pengukuran daya saing harus menggunakan patokan yang jelas, karena merupakan konsep yang relatif, baik untuk mengukur daya saing internasional maupun domestik. Laturffe (2010) mengatakan bahwa banyak penelitian yang menganalisis daya saing hanya dengan menggunakan satu ukuran (seperti indeks ekspor, biaya produksi, atau pertumbuhan produktivitas saja) meskipun telah terdapat bukti bahwa daya saing dapat berbeda sesuai dengan komponen yang diukur.

Indikator lain yang menjelaskan daya saing adalah indikator performance. Indikator performance dapat diukur dengan menggunakan beberapa variabel, diantaranya yang banyak digunakan untuk menjelaskan daya saing adalah produktivitas, profitabilitas, dan growth (Perdana, 2003; Malian et.al., 2004; Fischer \& Schornberg , 2007; Laturffe, 2010). Pendekatan dengan menggunakan variabel produktifitas, profitabilitas dan pertumbuhan output lebih dikenal dengan metode ICI (industrial competitive Indeks)

Pada metode ICI (Industrial competitive indeks) variabel profitabilitas sebagai bentuk faktor efektifitas yang mengukur keunggulan komparatif dari usaha ternak sapi potong. Variabel lainnya adalah produktivitas sebagai faktor efisiensi yang menjelaskan keunggulan kompetitif, dan variabel pertumbuhan output sebagai indikator dinamis dari usaha ternak sapi potong rakyat (Fischer \& Schornberg, 2007)

Profitabilitas merupakan salah satu indikator untuk menilai efektifitas dari suatu industri atau produk yang menunjukkan tujuan utama atau objektif yang akan dicapai. Untuk menentukan daya saing dari suatu perusahaan/ industri / negara dapat digunakan profitabilitas sebagai indikator untuk menggambarkan efektifitas. Menurut Purnama \& Setiawan, (2003), profitabilitas dapat menggambarkan kinerja dari suatu perusahaan atau industri yang berkorelasi dengan kompetensi pemasarannya. Ketika kinerja perusahaan tinggi, maka profitabilitas perusahaan akan ikut meningkat sehingga tingkat kompetensi perusahaan pada pasar juga ikut meningkat.

Produktivitas merupakan komponen yang turut menentukan dan menjadi syarat utama dalam keberhasilan suatu perusahaan. Produktivitas menunjukkan tingkat kualitas perusahaan dalam menghadapi era persaingan sehingga perusahaan dapat mencapai tujuan yang ditentukan. Porter (1990) menyatakan bahwa produktivitas merupakan akar penentu tingkat daya saing baik pada level individu, perusahaan, industri, maupun nasional/ Penjelasan ini didukung oleh (Laturffe, 2010) yang menyatakan bahwa produktivitas yang menunjukkan tingkat efisiensi dapat dijadikan salah satu ukuran utama untuk daya saing. Efisiensi juga dapat mengungkapkan potensi kompetitif yang dimiliki oleh perusahaan atau industri di masa yang akan datang.

Pertumbuhan merupakan aspek dinamis dari daya saing yang digunakan oleh Fischer \& Schornberg, 2007. Pertumbuhan output menjelaskan proses daya saing dari perusahaan/ industri.

Kelebihan pendekatan daya saing dengan indikator performance/ industrial Competitive Index (ICI) adalah kemungkinan untuk mempertimbangkan dua strategi bisnis, yaitu; (1) strategi pemasaran masal 
dengan produktivitas tinggi namun memiliki profitabilitas per unit yang rendah, dan (2) strategi "kualitas tinggi" dengan margin profit per unit yang tinggi dengan hasil produktivitas relatif lebih rendah (Fischer \& Schornberg, 2007)

\section{METODE PENELITIAN}

Penelitian menggunakan metode deskriptif. Data yang digunakan berupa data panel yaitu data time series dan cross section. Komponen data time series terdiri atas 6 unit yaitu tahun 2008 hingga 2013, sedangkan data cross section dalam penelitian ini terdiri atas 9 unit yakni merupakan Kecamatan Kecamatan yang ada di Kabupaten Mempawah. Sumber data yang digunakan berasal dari berbagai instansi, diantaranya adalah dari Badan Pusat Statistik, Dinas Pertanian Peternakan Perkebunan dan Kehutanan, mantri ternak, serta berbagai literatur dari berbagai intansi yang relevan dengan tulisan ini. Indikator data terdiri dari profitabilitas, produktivitas dan pertumbuhan output

Metode analisis yang digunakan dalam penelitian ini adalah pendekatan indeks mengenai daya saing usaha ternak sapi potong rakyat dengan menggunakan profitabilitas, produktivitas, dan pertumbuhan output dari peternakan sapi potong sebagai variabel terikatnya.

\section{Analisis profitabilitas,produktivitas dan pertumbuhan output \\ a. Profitabilitas}

$$
\text { PROs }=\frac{\mathrm{L} \quad \mathrm{P}}{\mathrm{n} \quad \mathrm{P}} \times 100
$$

Dimana

PROs : nilai profitabilitas usaa ternak sapi potong rakyat

Laba operasional : nilai penerimaan usaha diluar laba operasional (Rp)

Nilai penjualan : nilai penjualan ternak yang dipotong dan dikeluarkan (Rp)

\section{b. Produktivitas}

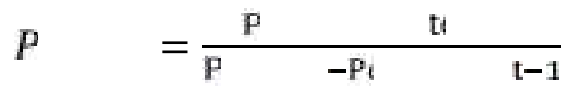

(Fischer \& Schornberg, 2007)

Dimana;

Prodks : Nilai Produktivitas usaha ternak sapi potong rakyat

Pengeluaran : Jumlah ternak sapi potong yang dapat dihasilkan dan dikeluarkan dari populasi per tahun/ periode

Pemasukan $_{(\mathrm{t}-1)}$ : Jumlah pemasukan ternak kecamatan selain impor, antar provinsi dan antar kabupaten/kota tahun $\mathrm{t}-1$

Populasi : Jumlah ternak yang terdapat di suatu kecamatan.

c. Pertumbuhan output

$$
\text { GROs }=\frac{\mathrm{p} t-\mathrm{p} \quad \mathrm{t}-1}{\mathrm{p} \quad \mathrm{t}-1}
$$

(Fischer \& Schornberg, 2007)

Dimana prod $_{t}=$ jumlah daging yang dihasilkan pada tahun $t$

$$
\text { prod }_{t-1}=\text { jumlah daging yang dihasilkan pada tahun } t-1
$$

\section{Analisis Daya Saing Usaha Ternak Sapi Potong Rakyat}

Analisis daya saing usaha ternak sapi potong rakyat sebagai fungsi dari profitabilitas, produktivitas, dan pertumbuhan output. Model persamaan yang digunakan dinyatakan sebagai;

$$
\text { COMPs }=f(\text { PROs, EFFs, GROs })
$$


Dimana;

COMPs : Competitiveness (Daya Saing) per satuan waktu

PROs : Profitabitas per satuan waktu

EFFs : Efisiensi per satuan waktu

GROs : Pertumbuhan Output per satuan waktu

Perubahan tingkat daya saing usaha ternak sapi potong rakyat dari waktu ke waktu, digunakan pendekatan agregasi perhitungan indeks yang merupakan metode sederhana untuk mengetahui perkembangan daya saing. Penggunaan indeks untuk daya saing menggunakan Industrial Competitiveness Index (ICI) dimana peringkat terakhir merupakan dasar dari analisis ini. Persamaan untuk menghitung indeks individu adalah sebagai berikut;

$$
I_{K}^{t i j}=\frac{M_{K}{ }^{t i}-M_{K}{ }^{\min }}{M_{K}{ }^{\max }-M_{K}^{\min }} \times 100
$$

(Fischer \& Schornberg, 2007)

Dimana I = Indeks Unit

$\mathrm{M}=$ Nilai Profitabilitas/Produktifitas/Pertumbuhan Output

$\mathrm{t}=$ tahun

i = wilayah

$\mathrm{k}$ = Variabel yang digunakan

Dengan diketahuinya indeks individu, maka langkah selanjutnya indeks tersebut disatukan dalam indeks daya saing industri (ICI). Kriteria keputusan dikatakan berdaya saing jika laju pertumbuhan meningkat (memiliki nilai positif).

\section{HASIL DAN PEMBAHASAN}

Hasil analisis menunjukkan bahwa indeks profitabilitas tertinggi ditempati oleh Kecamatan Sungai Pinyuh dan terendah oleh Kecamatan Siantan. Indeks produktifitas tertingggi ditempati oleh Kecamatan Anjungan dan terendah oleh Kecamatan Sungai Pinyuh. Indeks pertumbuhan output tertinggi ditempati oleh Kecamatan Toho dan terendah ditempati oleh Kecamatan Siantan. Sedangkan Indeks ICI peringkat tertinggi ditempati oleh Kecamatan Toho dan Indeks terendah oleh Kecamatan Siantan

Tabel 3. Hasil Analisis Indeks Kompetitif Industri Usaha Ternak Sapi Potong Rakyat Di Kabupaten Mempawah

\begin{tabular}{llcccc}
\hline \multirow{2}{*}{ No } & \multirow{2}{*}{ Kecamatan } & Prof & prods & Growth & ICI \\
\hline 1. & Siantan & 32,25 & 3,19 & 0,66 & 13,03 \\
2. & Segedong & 50,13 & 4,16 & 0,70 & 18,33 \\
3. & Sungai Pinyuh & $\mathbf{6 1 , 7 5}$ & 2,89 & 0,92 & 21,86 \\
4. & Anjungan & 39,96 & $\mathbf{2 9 , 3 3}$ & 0,97 & 23,42 \\
5. & Mempawah Hilir & 45,79 & 4,23 & 0,80 & 16,94 \\
6. & Mempawah Timur & 45,79 & 3,08 & 2,46 & 17,11 \\
7. & Sungai Kunyit & 61,41 & 6,76 & 0,75 & 22,97 \\
8. & Toho & 43,95 & 15,61 & $\mathbf{1 6 , 8 0}$ & $\mathbf{2 5 , 4 5}$ \\
9. & Sadaniang & 43,95 & 27,45 & 1,03 & 24,14 \\
\hline & Rerata & $\mathbf{4 7 , 5 5}$ & $\mathbf{1 0 , 7 4}$ & $\mathbf{2 , 7 9}$ & $\mathbf{2 0 , 3 6}$ \\
\hline
\end{tabular}

Sumber : Data diolah(2008-2013)

Hasil analiasis menunjukkan Nilai rerata indeks ICI tertinggi ditempati kecamatan Toho. Kecamatan Toho Menempati peringkat pertama karena indeks 
pertumbuhan output menempati rerata tertinggi . Ini dapat disebabkan karena ternak yang dipotong di Kecamatan Toho sudah memiliki berat yang ideal karena gizinya yang terpenuhi dikarenakan rumput mudah didapat karena luasnya lahan pertanian dan perkebunan ataupun pola pemeliharaan semi ranch. Dapat juga dikarenakan sapi yang dipotong merupakan persilangan bos taurus sehingga memiliki bobot potong yang tinggi. Menurut Subiharta et al., (2000), sapi peranakan Simental, PFH dan Limosin mempunyai ADG (Average Daily Gain/pertambahan bobot badan perhari) yang lebih besar dari pada sapi lokal seperti sapi PO dan bali.

Kecamatan Siantan memiliki indeks yang rendah karena rendahnya nilai indeks profitabilitas dan nilai indeks pertumbuhan output. Hal ini dapat disebabkan karena permintaan yang rendah serta letaknya yang berbatasan dengan Kota Pontianak sehingga harga lebih bersaing. Menurut Wulandari et.al., (2013).faktor faktor yang mempengaruhi harga daging sapi diantaranya adalah permintaan.

Menurut wanti (2013) nilai profitabilitas yang rendah di suatu daerah akan menyebabkan di daerah tersebut para peternak akan beralih pada pekerjaan yang lain yang menyebabkan akan berkurangnya populasi di daerah tersebut. Hal ini akan menyebabkan para peternak di kecamatan siantan akan beralih profesi yng menyebabkan turunnya populasi ternak di daerah tersebut. Hasil analisis menunjukkan selama enam tahun terakhir nilai indeks kompetitiv industri usaha ternak sapi potong rakyat Kabupaten Mempawah bernilai 20,36 \%..

Kecamatan sungai pinyuh menempati Indeks Profitabilitas tertinggi dapat disebabkan karena murahnya biaya operasional karena harga obat yang murah karena jaraknya dekat ke kota mempawah sehingga akses mantri hewan dalam pengobatan mudah. Tetapi di sisi lain memiliki harga jual yang tinggi akibat dari permintaan yang tinggi karena lokasi nya yang merupakan pertemuan dari 3 jalur strategis yakni arah kota Mempawah, arah kota Mempawah dan Arah ke Landak. Harga jual yang tinggi ini dapat disebabkan karena permintaan daging yang tinggi tidak dibarengi dengan produk yang seimbang. Menurut Wulandari et.al., (2013).faktor faktor yang mempengaruhi harga daging sapi diantaranya adalah permintaan.

Hasil analisis menunjukan nilai produktifitas tertinggi ditempati oleh kecamatan anjongan. Kecamatan anjongan menempati nilai tertinggi karena ternak yang dikeluarkan lebih banyak ketimbang ternak yang masuk. Hal ini dapat disebabkan karena angka kelahiran yang tinggi. Angka kelahiran yang tinggi dapat diprediksi dengan banyaknya populasi sapi betina. Untuk meningkatkan produktifitas dapat dengan meningkatkan jumlah betina produktif ataupun dengan penyelamatan betina produktif dan perbanyakan reproduksi baik dengan kawin alam maupun dengan penggunaan teknologi Inseminasi Buatan (IB) agar sapi yang dihasilkan mencukupi sehingga mampu untuk diproduksi keluar. Menurut Susilawati \& Affandi (2004) Inseminasi Buatan Merupakan salah satu teknologi reproduksi untuk meningkatkan produktifitas ternak yang sudah bisa diterapkan ke masyarakat.

Selain itu untuk melengkapi ketidak lengkapan data dan volaitilitas/pergerakan data yang tinggi maka data dikelompokkan menjadi minimal 2 kelompok dengan rentang 1 kelompok terdiri dari 3 tahun (deret aritmatika). Data laju pertumbuhan di sajikan pada tabel 4. 


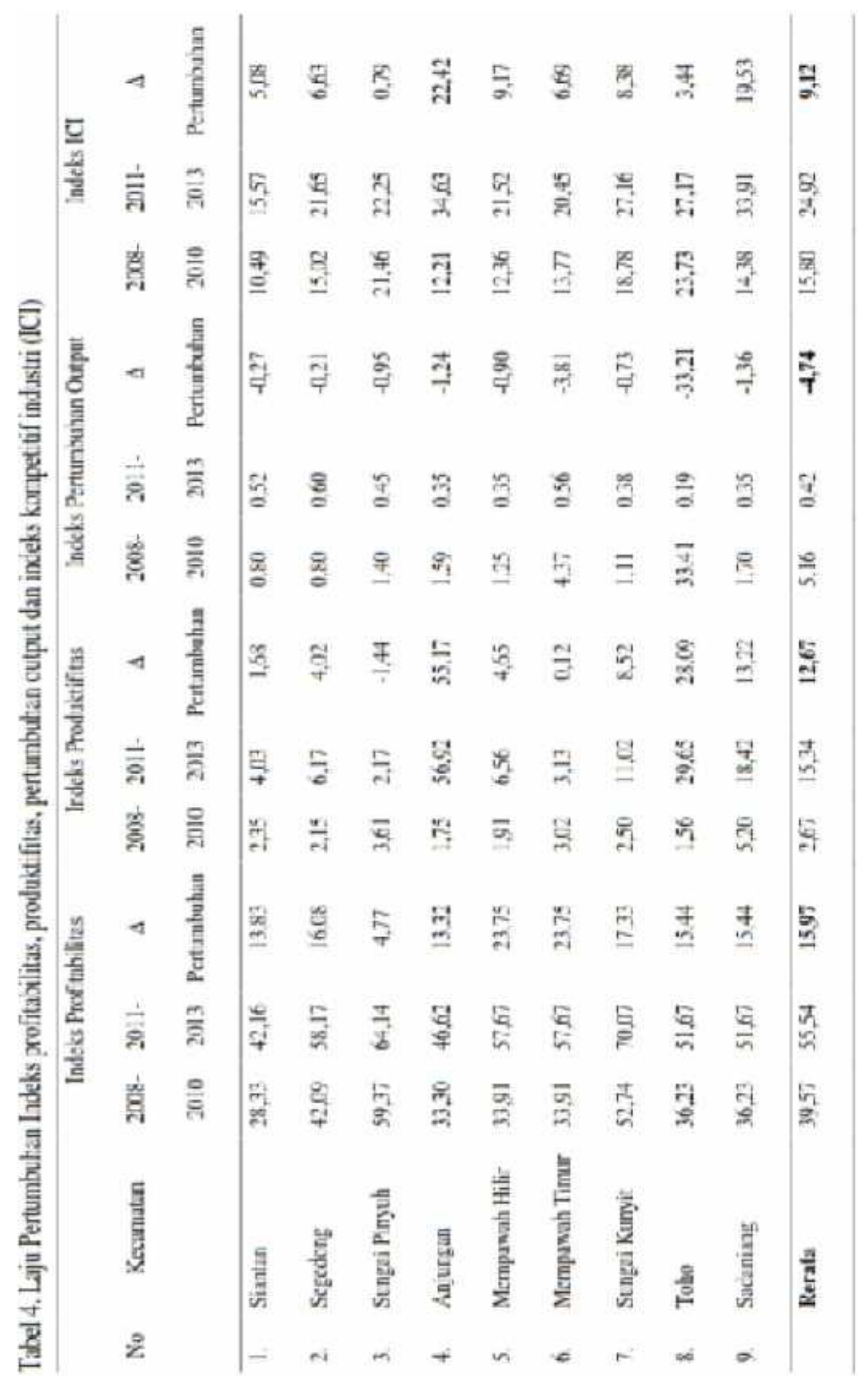


Pada laju pertumbuhan indeks competitive industri periode pertama dan periode kedua keseluruhan kecamatan mengalami laju peningkatan dengan nilai terendah pada Kecamatan Sungai Pinyuh sedangkan nilai tertinggi didapat pada Kecamatan Anjungan. Kecamatan anjungan menempati laju pertumbuhan tertinggi dapat disebabkan karena tingginya laju petumbuhan indeks profitabilitas. Hal ini dapat disebabkan karena meningkatnya laba produksi karena murahnya harga pakan. Menurut Diwyanto \& Haryanto (2002), integrasi ternak dengan tanaman, baik itu pangan maupun perkebunan, memberikan nilai tambah yang cukup tinggi. Selain itu Menurut Hadi \& Ilham(2002), usaha penggemukan lebih banyak di daerah dataran tinggi dengan ketersediaan pakan relatif cukup,sedangkan usaha pembibitan umumnya dilakukan di daerah dataran rendah dengan pakan relatif kurang. Sapi yang akan dipotong akan mengalami fase penggemukan, oleh sebab itu daerah anjungan yang termasuk dataran tinggi memiliki ketersediaan pakan yang relatif cukup.

Pada laju pertumbuhan indeks profitabilitas, seluruh kecamatan mengalami peningkatan dengan nilai rata rata $15,97 \%$. Pada laju pertumbuhan indeks produktifitas seluruh kecamatan mengalami peningkatan kecuali Kecamatan Sungai Pinyuh dengan nilai rata rata pertumbuhan 12,67\%. Pada laju pertumbuhan indeks pertumbuhan outuput seluruh kecamatan mengalami penurunan dengan nilai $-4,74$. Pada laju pertumbuhan indeks kompetitif industri keseluruhan kecamatan mengalami laju peningkatan dengan nilai terendah pada Kecamatan Sungai Pinyuh sedangkan nilai tertinggi didapat pada Kecamatan Anjungan. Secara umum Kabupaten Mempawah memiliki laju pertumbuhan indeks daya saing industri sebesar 9,12\%.. Hasil yang berbeda diperoleh menurut penelitian Wanti (2013), provinsi Kalimantan Barat memiliki nilai indeks daya saing peringkat 3 diantara 21propinsi daerah prioritas sapi potong pada periode 2003-2006 sebesar 29,72\% dan kemudian menjadi peringkat 13 pada periode 2007-2010 sebesar 29,25\%. Hal ini berarti mengalami laju penurunan (negatif $0,47)$. Perbedaan pertumbuhan nilai pertumbuhan output ini dapat disebabkan karena perbedaan ruang lingkup penelitian antara provinsi Kalimantan Barat dengan Kabupaten Mempawah.

Dengan laju pertumbuhan indeks yang bernilai positif maka dapat dikatakan bahwa usaha ternak sapi potong di 9 kecamatan di Kabupaten Mempawah masih memiliki kemampuan berdaya saing oleh karena itu masih layak untuk dikembangkan.

\section{KESIMPULAN}

Berdasarkan hasil analisis data dan pembahasan pada bab sebelumnya, maka dapat diambil kesimpulan sebagai berikut :

1. Nilai Indeks Profitabilitas memiliki laju pertumbuhan indeks seluruh kecamatan yang meningkat yang berarti masih layak dikembangkan kebijakan untuk meningkatkan indeks profitabilitas dan mempertahankan pertumbuhan indeks profitabilitas yakni dengan meningkatkan produksi dengan sistem terintegrasi peternakan pertanian dan perkebunan.

2. Nilai Indeks Produktifitas memiliki laju pertumbuhan indeks seluruh kecamatan mengalami peningkatan kecuali Kecamatan Sungai Pinyuh yang mengalami penurunan yang berarti perlu perhatian khusus. Untuk meningkatkan indeks produktifitas dan meningkatkan laju pertumbuhan 
indeks produktifitas dengan meningkatkan populasi dan angka kelahiran,yakni dengan perbanyakan dan penyelamatan betina produktif dan dengan peningkatan reproduksi dengan teknologi Inseminasi Buatan (IB) sehingga dapat mengurangi pemasukan dari luar.

3. Nilai indeks pertumbuhan memiliki laju pertumbuhan indeks seluruhnya mengalami penurunan karena itu perlu kebijakan pemerintah dalam mendongkrak pertumbuhan output dengan menggunakan teknologi Inseminasi Buatan dengan semen sapi persilangan seperti sapi Bos Taurus dan dengan mengoptimalkan manajemen pemeliharaan sehingga masa panen cepat

4. Nilai Indeks Competitif Industri (ICI) memiliki laju pertumbuhan seluruh kecamatan mengalami peningkatan karena itu usaha tersebut masih dikatakan berdaya saing sehingga masih layak untuk dikembangkan

5. Perlu pengujian secara statistik agar penelitian mendapatkan hasil yang lebih valid secara statistik.

\section{DAFTAR PUSTAKA}

Ambastha A, Momaya K. (2004). Competitiveness of firmsreview of theory, frameworks and models. Singapore Manag Rev. 26:45-61.

Bhinadi, A. (2003). Disparitas Pertumbuhan Ekonomi Jawa dengan Luar Jawa. Jurnal Ekonomi Pembangunan , 8 (1), 39-48.

Bojnec $\breve{S}$, Ferto I. 2009. Agro-food trade competitiveness of Central European and Balkan countries. Food Policy. 34:417-425.

Cook ML, Bredahl ME. (1991). Agribusiness competitiveness in the 1990s: discussion. Am J Agric Econ. 73:1472- 1473.

Diwyanto, K. dan B. Haryanto. 2002. Pakan alternatif untuk pengembangan peternakan rakyat. Rakor Pengembangan Model Kawasan Agribisnis Jagung TA 2002. Direktorat Jenderal Pengolahan dan Pemasaran Hasil Pertanian, Jakarta 29 April 2002.

Fischer, C., \& Schornberg, S. (2007). The Competitiveness Situation of The UE Meat Processingand Beverage Manufacturing Sectors. Dalam Foods Economics -Acta Agricultural Scand C (hal. 148-158).

Hadi, P.U., \& Ilham, N. (2002). Problem dan Prospek Pengembangan Usaha Pembibitan Sapi Potong di Indonesia . Jurnal Litbang Pertanian 21(4), 148-158.

Hadi, P., \& Mardianto, S. (2004). Analisis Komparasi Daya saing Produk Ekspor PertanianAntar Negara Asean Dalam Era Perdagangan Bebas AFTA. Jurnal Agro Ekonomi , 22 (1), 46-73.

Ketels, C. (2006). Michael Porter's Competitiveness Framework-Recent Learning and ew Reseach Priorities. Journal of Industry, Competition and Trade 6 (2), 115-136.

Krugman PR. (1994). Competitiveness: a dangerous obsession.Foreign Aff. $73: 28-44$.

Laturffe, L. (2010). Compettiveness, Productivity, And Efficiency in the Agricultural and Agri-Food Sector. (30). 
Malian, A. H., Benny, R., \& Adimesra, D. (2004). Permintaan Ekspor dan Daya Saing Panili di Provinsi Sulawesi Utara. Jurnal Agro Ekonomi , 22 (1), 2645.

Martin, L., R. Westgren and E. van Duren (1991): Agribusiness Competitiveness across National Boundaries. American Journal of Agricultural Economics 73:1456- 1464

Notta, O., \& Vlachvei, A. (2011). Competitiveness in Food and Beverage Manufacturing Industries. ICOAE.

Perdana. (2003). Competitiveness and Comparative Advantage of Beef Cattle Fatening in Bandung Regency. Bandung: Padjajaran University. http://www.stanford.edu/group/FRI/indonesia/research/beef.pdf

Porter, M. E. (1990). The competitive Advabtage of Nations. The free Press. New York

Priyanti, A., Mahendri, I., Kusnadi U. (2014). Dinamika Daging Sapi di Wilayah Sentra Usaha Sapi Potong di Indonesia. Jurnal Litbang Pertanian 21(4), 148-158.

Purnama, N., \& Setiawan, H. (2003). Analisis Pengaruh Sumber Sumber Keunggulan Bersaing Bidang Pemasaran Terhadap KInerja Perusahaan Manufaktur di Indonesia. Jurnal Siasat Bisnis , 8 (2), 105-130.

Siggel E. 2007. International competitiveness and comparative advantage: a survey and a proposal for measurement. In: CESifo Venice Summer Inst 2007. Venice, 16-21 July 2007. Venice (Italy): CESifo. p. 1-33.

Subiharta, U.,Nuschati, B., Utomo, D., Pramono, S., Prawirodigdo,T., Prasetyo, A., Musofie., Ernawati, J., Purmiyanto \& Sudarsono. (2000). Laporan Hasil Kegiatan Pengkajian Sistem Usaha Tani Pertanian Sapi Potong di Daerah Lahan Kering Malang :BPTP Ungaran

Susilawati , T.,\& Affandy, L., (2004). Tantangan dan Peluang Peningkatan Produktifitas Sapi Potong Melalui Teknologi Reproduksi.Dalam Lokakarya Nasional Sapi Potong. Malang :Universitas Brawijaya

Wanti, P. I. N. (2013). Analisis Daya Saing Industri Penggemukan Sapi Potong Lokal di Indonesia . Dalam Tesis. Bogor: Sekolah Pasca Sarjana IPB.

Wulandari ,W.A., Supriana, T., Jufri, M. (2014). Faktor Faktor Yang Mempengaruhi Harga Sapi di Sumatera Utara. Jurnal on Social Economic of Agriculture and Agribisnis. Vol 3 (9) 